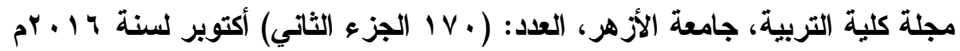

\title{
The Practicum Problems as Viewed by the Female Student Teachers at Princess Nourah Bint Abdulrahman University
}

\begin{abstract}
:
The current study aimed to identify the problems encountered by the student teachers during the practicum period in relation to the academic supervisor, cooperating teacher, cooperating school and student teachers. The present study adopted the descriptive approach as it is based on data collection in order to answer the questions of the study. The participants of the study were (70) level eight English branch female student teachers who were enrolled in the practicum program during the second semester of the academic year (1436-1437 A. H.). For fulfilling the purpose of the current study, the researcher developed a questionnaire investigating the problems encountered by the student teachers (from their points of views) in relation to the following dimensions: the academic supervisor, cooperating teacher and cooperating school, as well as the problems caused by the student teachers themselves. The main problems investigated were arranged as follows: The cooperating school, the student teacher, the academic supervisor and he cooperating teacher. Recommendations were developed in the light of the results attained.
\end{abstract}

Keywords: the practicum program, the student teacher, the academic supervisor, the cooperating teacher, the cooperating school.

\section{Introduction:}

The significance of the practicum program lies in the fact that the student teachers are the future teacher who should be thoroughly prepared. It is not worthwhile to prepare the teachers theoretically and ignore their abilities to functionalize the theoretical knowledge practically to meet the needs of the school environment.

The practicum period is noteworthy for the student teachers preparation programs. Zichner (1990) suggested that the 
مجلة كلية التربية، جامعة الأزهر، العدد: ( • V الجزء الثاني) أكتوبر لسنة 1 ا • rم

practicum programs in the European universities were unarranged experience as the student teachers work individually without systematic observations from the cooperating teacher or the academic supervisor. Furthermore, the cooperating schools paid the due attention to their students and ignored their crucial part in preparing the student teachers for their future career (Shaheen, 2010). Learning is the key of development, and we cannot consider the type of instruction without having academically well-qualified and trained teachers as the teacher's role is not only restricted to learning and teaching but it includes the socialization processes in general (Shaheen, 2010, P.48).

The societies considerable changes, namely, demographic, educational, social, economic and technological changes, necessitate effective educational systems which entail improving the quality of the teacher preparation because the educational field with all its new implications and challenges needs people who are armed with novel experiences, thoughts, techniques and skills for achieving better ways of dealing. Ibrahim (2003) asserted the importance of teacher preparation in relation to improving his abilities and skills and developing his behavior in concordance with the requirements of the teaching profession. Furthermore, the preparation process should take into consideration raising the teacher's awareness concerning the society changes (Ibrahim, 2003 as cited in Shaheen, 2010. P. 173).

The period of the practicum significantly contributes in updating the student teachers with the requirements of the teaching profession, the features of the successful teacher and the effective methods of teaching. Consequently, it is of crucial importance to explore the problems encountered by the student teachers during the practicum program in order to achieve qualitative improvements in administering the practicum programs to make the students able to adapt with the related rapid changes and the scientific and the technological developments in different fields.

The practicum period is one of the stressful periods experienced by the student teachers as they encounter many problems. Whereas, this period is one of the richest learning periods during the student teachers' life as they acquire numerous 


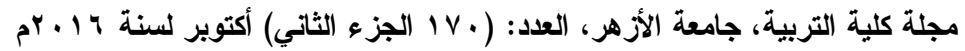

practical skills that they may not face during their future professional life. Consequently, developing better programs for the student teachers entails intense awareness of those directly involved in the practicum program who should possess skills that might contribute in providing appropriate feedback and enhance the student teachers' abilities in planning, implementing and evaluating the teaching learning process.

\section{Context of the Problem:}

The practicum program is the cornerstone of the teacher preparation programs at the faculties of education as it provides the student teachers with the opportunities to functionalize the acquired theoretical knowledge practically to be translated into practical experiences. As the practicum period is a cooperative process participated among the student teacher, the academic supervisor, the cooperating teacher and the cooperating school, there are many difficulties encountered by the student teachers during the practicum period. The researcher detected the study problem through:

1. Working as an academic supervisor for the eighth level English Branch students. With this in mind, many student teachers revealed many difficulties and problems encountered during the practicum period. The sources of the problems mentioned were those participating in the practicum program, namely, the cooperating teacher, the academic supervisor and the cooperating school. The student teachers are the focus of the practicum program, so their opinions concerning the positive and the negative effects of those participating in the practicum program are of crucial importance.

2. The continuous complaints of the cooperating teachers concerning the student teachers' performance.

3. The continuous complaints of the cooperating school administration concerning the student teachers' performance. 


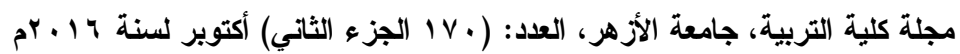

With this in mind, the main objective of the present study was portrayed which was directed to identifying the sources of the student teachers encountered problems.

4. The weakness of the student teachers' performance as noted by the academic supervisors.

5. The previous studies portrayed the social, academic and administerative problems faced by the student teachers during the practicum period.

Questions of the Study:

Question One:

- What are the problems, encountered by the student teachers during the practicum period, related to the academic supervisor?

Question Two:

- What are the problems, encountered by the student teachers during the practicum period, related to the cooperating teacher?

Question three:

- What are the problems, encountered by the student teachers during the practicum period, related to the cooperating school?

Question Four:

- What are the problems, encountered by the student teachers during the practicum period, related to the student teacher?

Significance of the Study:

The significance of the current study lies in the fact that it deals with an important problem directly linked to the student teachers' preparation and training through:

1. Providing clear and real image of the problems encountered by the student teachers during the practicum program. 


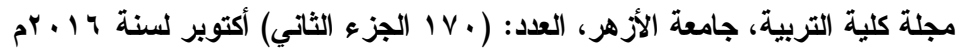

2. Probing the problems encountered by the student teachers according to their points of views.

3. Evaluating those participating in the practicum program (the cooperating teacher/ the academic supervisor/ the cooperating school administration).

4. Responding to the current trends calling for rehabilitating the student teachers in concordance with the modern developments.

5. Developing feedback for those responsible for the practicum program in order to maintain the practicum program points of strength and modify the points of weakness to provide suitable training environment for the student teachers and the cooperating teacher.

\section{Terms of the Study:}

The Student Teacher:

The eighth level female student teacher enrolled in the English Branch, Curriculum and Instruction Department, Faculty of Education who is enrolled in the practicum program in one of the cooperating schools in Riyadh during the practicum program period.

\section{Cooperating Teacher:}

The teacher who is formally assigned for enabling the student teachers perform the gradual teaching through guiding, supervising and allowing the student to teach some sessions under her supervision and evaluation partially.

Academic Supervisor:

One of the educational staff members (lecturer - assistant professor - associate professor - professor) who holds the responsibility for supervising some of the student teachers through guidance, follow up and evaluation during the practicum period. 
مجلة كلية التربية، جامعة الأزهر، العدد: ( • V الجزء الثاني) أكتوبر لسنة 1 ا • rم

Cooperating Teacher:

The school in which the practicum program is taking place for a period of time assigned for the practicum in coordination with the Practicum Program Unit (at the faculty) for identifying the school ability to train the assigned students and provide the suitable circumstances for achieving the best gains of the practicum program.

\section{Problems:}

The difficulties related to the activities and the instructional skills that are encountered by the English branch student teachers in the cooperating schools as identified by the responses of the study participants concerning the main and the sub-items of the questionnaire.

\section{Delimitations of the Study:}

The current study was delimited to the points of views of the student teachers enrolled in the practicum program during the second semester of the academic year (1436 / 1437 A.H.) at the Faculty of Education, Curriculum and Instruction Department, English Branch.

\section{Method and Procedures:}

Participants of the Study:

The population of the current study were all the student teachers at the English Branch who were enrolled in the practicum program during the second semester (1436/1347 A.H.). The participants of the study, totaling (62) student teachers, were randomly selected representing about $(20 \%)$ of the study population.

\section{Instrument of the Study:}

The researcher developed a questionnaire based on the previous related literature and the responses of the eighth and the seventh level student teachers for questions posed by the researcher in the previous semesters as the student teachers are the cornerstone of the program. Furthermore, the researcher investigated the academic supervisor views of the practicum 


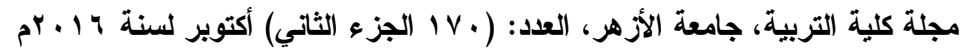

program and made use of the experiences gained from supervising the students enrolled in the practicum program.

The initial form of the questionnaire included (48 items) under for main dimensions related to the sources of the practicum problems, namely, the student teacher, the academic supervisor, the cooperating teacher and the cooperating school. Each item of the questionnaire was given five degrees.

\section{Validity of the questionnaire:}

The questionnaire was submitted to a panel of jury specialized in education to assure its validity and get their points of views and feedback concerning every item (problem) as it whether belong or not to its main dimension. Furthermore, they defined the items to be modified or deleted. The items of the questionnaire were modified and reformulated in its final form, in the light of the jury feedback, to be (47) items under the previously mentioned dimensions.

\section{Reliability of the questionnaire:}

The internal consistency of the questionnaire via Cronbach Alpha of the main dimensions and the total degrees was calculated. The results showed that the internal consistency coefficient of the questionnaire was (5.86) which is considered acceptable and indicate high consistency.

\section{Procedures of the Study:}

The current study pursued the following steps:-

1. Assigning the participants of the study to be the English Branch student teachers enrolled in the practicum program during the second semester of the academic year (1436 / 1437 A.H.).

2. Reviewing the previous literature related to the present study.

3. Preparing the questionnaire (the instrument of the study) and assuring its validity and reliability. 
مجلة كلية التربية، جامعة الأزهر، العدد: ( • V الجزء الثاني) أكتوبر لسنة 1 ا • rم

4. Distributing the questionnaire to the study participants (the student teachers) during the second semester (1436 / 1437 A.H.).

5. Collecting and analyzing the attained data statistically using the Statistical Package for Social Science (SPSS) in order to get the results of the study and present the discussion and recommendations.

\section{Design of the Study and the Statistical Analysis:}

The current study adopted the descriptive curriculum to provide a detailed description of the student teachers' problems related to the academic supervisor, the cooperating teacher and the cooperative school. The degree of the each problem was transformed into numerical values graded from one to five to be suitable in the statistical analysis as follows:

- The problem is clear very severe (5 degrees), the problem is severe (4 degrees), the problem is moderate ( 3 degrees), the problem is not severe ( 2 degrees), there is no problem ( 1 degree).

- The data obtained were statistically analyzed via SPSS using many statistical techniques, namely, the arithmetic means, standard deviations and percentages. Data were analyzed and interpreted in order to identify the problems and calculate the proportional importance of each of which.

\section{Previous Studies:}

1. Al-Sayda and Mahasna's Study (2015)

The study aimed at exploring the problems encountered by the student teachers specialized in the professional education at Al- Balqa' Applied University during the practicum period. The sample of the study consisted of 30 students (males and females) enrolled in the practicum program of the professional education specialization. The students were enrolled in the bachelor and the diploma degrees. The participants of the study were about $(81 \%)$ of the study population. The instrument of the study was a 54-item questionnaire including five main dimensions. The results of the 
مجلة كلية التربية، جامعة الأزهر، العدد: ( • V الجزء الثاني) أكتوبر لسنة 1 ا • rم

study showed that the problems encountered by the student teachers during the practicum program were moderate and the most important ones were arranged as follows:

(The problems related to the students, the problems related to the professional education curricula, the problems related to the supervision, the problems related to the cooperating schools and the problems related to the educational preparation of the student teachers). The results of the study, also, showed weaknesses in the school supervision of the student teachers and revealed that there was a negative views towards the student teachers as the cooperating teachers did not like them. The study results showed that the student teachers who were enrolled in the bachelor degree were average students, which indicated that their motivation towards work was poor. The study recommended increasing the practicum time to be a full semester, ensuring coordination among the university and the schools, improving communication among the supervisors and the student teachers.

2. Khasawna's Study (2014)

The study aimed at evaluating the effectiveness of the practicum program at the University of Hail as viewed by the student teachers and exploring the impact of changing the cumulative average of the student on evaluating the practicum programs. The deliberate sample of the study consisted of (186). The instrument of the study was a valid and reliable questionnaire consisted of (61) items. The results of the study showed that the student teachers' evaluation of the practicum programs were arranged as follows: evaluation of the practicum supervisor, the cooperating teacher, the procedures of the practicum program, the cooperating school and the cooperating school manager. The results of the study underscored no differences in evaluating the student teachers of the program in relation to the effectiveness of the practicum program that may be attributed to the cumulative average.

3. Al-Aagez and Hels' study (2011).

The study aimed at exploring the roles of the faculty of education, the academic supervisor, the cooperating teacher and the school managers in developing the practicum program of the 
مجلة كلية التربية، جامعة الأزهر ، العدد: ( • V الجزء الثاني) أكتوبر لسنة 14 • بام

student teachers. Moreover, the study aimed at delineating the most important problems encountered by the student teachers. The researchers adopted the descriptive analytical curriculum and developed a questionnaire consisting of (72) items was submitted to the study sample which was consisted of (183) student teachers (male and female). The results of the study indicated that the most severe problems encountered by the student teachers was the lack of the assisting instructional media at the cooperating schools and the school administration negligence of the student teachers. The study recommended viewing the practicum period as a cooperative process among the student teacher, the cooperating teacher, the school manager, the educational supervisor and the faculty of education.

\section{Almotlk's Study (2010)}

The current study aimed at portraying the importance the practicum programs in preparing the student teachers for their future careers, investigating the views of the academic supervisors concerning the program and exploring the views of the fourth grade students (class teacher specialization), Faculty of Education, Damascus University. The researcher probed the program points of strength and weakness. The study also investigated the status quo of the practicum program at schools and the difficulties encountered by the student teachers and the teachers in relation to the program, the student teachers, the academic supervisor, the school administration, and the lessons planning and implementing using different techniques of instruction. The study cited many related studies and presented the results attained.

\section{Shaheen's Study (2010).}

The study aimed at identifying the practicum problems encountered by the student teachers at Al-Quds Open University and their relationships to gender and specialization. An instrument was developed, for fulfilling the purpose of the study, consisting of (40) items under four main dimensions. The sample of the study consisted of (246) student teachers (males and females). The results obtained showed that there were statistically significant differences between gender (male and female) in relation to the problems faced during the practicum period in 


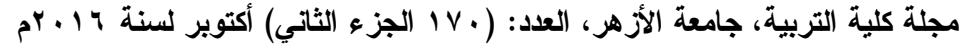

favor of the females as they suffered more than males in all dimensions. Furthermore, Math Branch students suffered more than other department students did. The problems encountered by the student teachers were related to the academic supervisors, cooperating teacher, lesson planning and the cooperating school students. The study recommended conducting many in-depth investigations related to the problems encountered by the student teachers during the practicum period.

6. Al-Khwalda and Ahmida's Study (2010).

The study aimed at portraying the problems encountered by the student teachers specialized in children education at Queen Rania Faculty for Childhood, Hashemite University during the practicum period. For fulfilling the purpose of the current study, a questionnaire was designed consisted of (52) items under six main dimensions. The sample of the study consisted of (155) student teachers. The results of the study showed that the practicum problems were related to the cooperating kindergarten school, the practicum program, the student teacher personality, the academic supervision, the cooperating teacher and the planning and implementing of the lessons. The results of the study showed that there were statistically significant differences between the mean scores of the practicum problems related to the gender. On the other hand, there were no problems related to the cumulative average of the students. In the light of the results attained, it was suggested developing the practicum program in concordance with the universal standards, developing strategies for overcoming the problems encountered by the student teachers and conducting many strategies related to the problems detected.

7. Al-Masry's Study (2010).

The current study aimed at identifying the problems encountered by the students enrolled in the practicum program at the Branch of Physics, Faculty of Education, Al-Aqsa University in Gaza. The sample of the study consisted of (39) students (the population of the study). The researcher adopted the descriptive analytical curriculum. The researcher made use of a survey for exploring the practicum restrictions developed by Bdor AbdulAllah Al-Motawaa after adjusting the survey form to suit the 


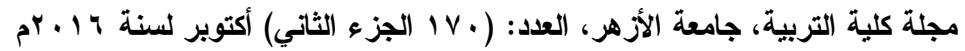

Palestinian environment. The results of the study showed that there were many problems encountered by the practicum student teacher during the time of training. The problems encountered were, namely, the school management, the physical education lessons, the academic preparation lessons, the guiding resources and the materials available. The study showed that there were no differences in relation to the gender.

8. Abo Shendy, et.al. Study (2009)

The study aimed at evaluating the components of the practicum program at Zarqa Private University, namely, the academic supervisor, the cooperating teacher, the school manager, the cooperating school and the procedures of the practicum program as viewed by the student teachers and the teachers. Furthermore, the study aimed at exploring the effect of the gender variable, the region of training, the cumulative average of the student teachers and the student teachers' evaluation of the practicum program. The sample of the study consisted of (96) students (males and females) were selected via multi-stage method. A questionnaire, consisting of (59) items, was developed for fulfilling the purpose of the current study. The results of the study revealed that the evaluation process involved evaluation of the academic supervisor, the cooperating teacher, the practicum program procedures, the cooperating school and the cooperating school manager. The results showed that there were no statistically significant differences at $(0.059<)$ in evaluating the student teachers of the practicum program that may be attributed to the gender of the student or the cumulative average. The study showed that there were statistically significant differences in the student teachers' evaluation of the cooperating school manager.

9. Khazer's Study (2007)

The study aimed at identifying the practicum problems encountered by the cooperating schools managers from their points of views. The study also aimed at portraying the effect of the school, the numbers of student teachers and the remoteness of the cooperating school from the university center on the encountered problem in the cooperating school. The sample of the study consisted of (151) main schools $(81 \%)$ of the study 


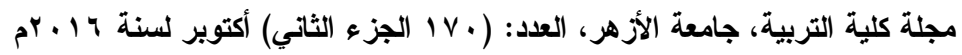

population. A questionnaire, consisting of (45) items, was developed for fulfilling the purpose of the current study. The results obtained revealed that the problems were related to the practicum program, the student teacher, the academic supervisor. The results also showed that the school managers (male of female) were not affected by the gender variable. The study confirmed that their evaluation was affected by the variables of the trained students and the remoteness of the cooperating school from the university center.

10. Al-Astal's Study (2004)

The current study aimed at identifying the problems encountered by the student teachers at the College of Education and the Basic Sciences, Ajman University of Science and Technology during the practicum period and identifying the variance of these problems due to the gender and specialization. A questionnaire was developed consisting of (43) items under six main dimensions, namely, the practicum program, the cooperating school, the academic supervisor, the student teacher personality, the cooperating teacher and planning and implementing of the lessons for fulfilling the purpose of the study. The sample of the study consisted of (213) student teachers. The questionnaire was administered during the second semester (2001/2002). The results of the study showed that the major problem was the practicum problem and the minor problem was the academic supervisor. The study showed that the problems among the female student teachers were more severe than those of male student teachers. The study showed that the student teachers' specialization has no effect on the encountered problems. The study recommended the importance of developing the practicum program and overcoming the problems faced by the student teachers inside the cooperating schools.

\section{Sokal and woloshyn's Study (2013)}

A pilot study was conducted investigating self-confidence, fears, teaching effectiveness before and after attending a training course about comprehensive learning. The study included (60) student teachers and some students who participated in the practicum program and some scholastic courses. 


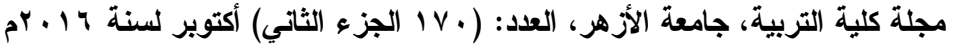

The two groups benefited from the experiment and achieved considerable gains in relation to the entire dependent and sub variables. The student teachers who took part in the practicum program achieved high effectiveness in the classroom management and the student teachers who participated in the program succeeded and achieved high scores in contrast to their peers who did not participate.

The study confirmed the importance of cooperation among the cooperating schools and the universities for providing effective comprehensive strategies for developing student teachers' performance. The study, also, confirmed the importance of integrating both the scholastic courses and the practicum program to create a comprehensive environment for developing the teachers' confidence and effectiveness and decrease the degrees of anxiety.

The study administered a questionnaire consisting of three parts: the first part involved information about the population structure, the second part included the fears concerning the university education standard, and the third part encompassed the teachers' efficacy concerning the comprehensive management. The results of the study showed that the student teachers who graduated from the teacher preparation program had limited aptitude, which in turn made them reject the teaching career after graduation. Furthermore, designing high quality preparation programs assisted in investing the time and resources for comprehensive preparation for teachers, which in turn assisted in increasing the teacher teaching efficiency.

The results of the study confirmed that the teachers who gained positive experiences demonstrated deep understanding of the children and class needs and other important components related to the teacher experiences. Furthermore, the study helped the student teachers to identify the problems encountered by the students and understand their social needs which in turn assisting in developing the individual instructional planning and providing different instructional strategies. Moreover, the practicum program helped in forming deep understanding of the children with special needs and their families. The practicum program also assisted in transforming the theory into practice inside the

$$
-V Y \leq-
$$


classroom setting. The concluding results confirmed that the new practicum program (SET) was successful, enjoyable and profitable. Moreover, the most important feature for this program was that it helped in understanding the students' needs and linking the theory to the practice (SET).

12. Nonis and Jernice's Study (2011)

Student teachers specialized in special education in Singapore were trained for 10 weeks in a private school. The student teachers met their pupils and formed ideas about the classroom management system, the scholastic culture and the school administrative processes.

The student teachers were guided by the school and the university supervisors and the cooperating teachers in the lessons planning. The study focused on the learning experiences among the teachers during the practicum period. The sample of the study consisted 33 students (3 males and 30 females). According to likret, the survey was administered which included two parts:

a) Student teachers' responding towards the practicum experience.

b) Steps of the practicum program (SET).

The results attained showed that the student teachers suffered from professional strain during the practicum period and indicated that the experiences acquired during the practicum period helped in developing the skills and competencies for the classroom management and the teaching profession (Cameron, Giat, Purger, 2007; Hynper 1994; and Smith, Leef \& Aray 2005). The following question were the main focus of the training:

1) What were the teachers' experiences during the practicum period (SET)?

2) Was the practicum experience comprehensible by those participating in the practicum program?

3) What were the factors helped in forming positive experiences? 


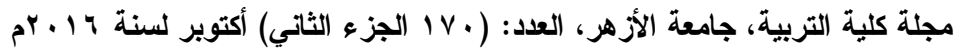

4) What were the difficulties encountered by the student teachers?

5) What were the student teachers expectations of the (SET) program?

13. Allen, Ambrosetti, and Turner's Study (2013)

The current study portrayed a research conducted in two universities in Australia to assess the factors affecting the teachers' professional experiences during the practicum program in Tasmania and Queensland and identify the effectiveness of the practicum program in helping the student teachers integrate the knowledge and skills acquired at the university practically.

The study sample consisted of (265) teachers. The study used the statistical survey and the interviews to gather data concerning the participants' expectations of the practicum program. The study adopted a likert scale questionnaire which included (30) objective questions and (6) open ended questions.

The results, which were based on comparisons, showed the importance of the theoretical part for the practical one and the importance of participation to facilitate the integration during the practicum program and provide the suitable environment. Furthermore, the study showed the importance of participation between the school and the university in order to achieve effective success in the practicum program. On the other hand, the study results showed that developing authentic partnership among the schools and the universities assisted in filling the gap between the theory and the professional practices, improving the practicum experiences of the student teachers, and providing sufficient materials for both sectors.

The results of the study indicated that some student teachers were dissatisfied during the period of the practicum because of the severe stress due to the supervision, misunderstanding of the students' needs, training time insufficiency and lack of time to be spent with each student alone. 


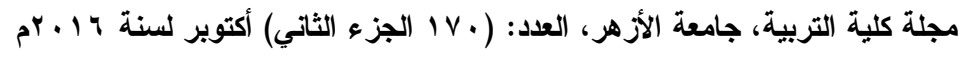

14. Kiggundu's Study (2007)

The study aimed at identifying the problems encountered by the student teachers at Vall Technological University and portraying the positive and negative sides that faced the student teachers during the practicum program in order to achieve the potential objectives of the teaching process. The participants of the study were (24) post-graduate students seeking the teaching certificate (PGCE) during the practicum period (10 weeks).

The qualitative approach was adopted in the pilot study, which was administered in different schools in Vall triangle reign. Interviews were conducted with the study sample. The results attained showed that student teachers were professionally prepared to transform the theoretical knowledge to practical performance. It was also revealed that the challenges faced by the student teachers were attributed to preparation during training, the nature of relationship among the student teachers and the cooperating teachers, the cooperating teachers, classroom management and the insufficiency of the financial resources and materials. The study recommended the importance of training in the non traditional schools as the traditional ones caused severe stress on the student teachers and teachers and forming negative attitudes among the student teachers. Furthermore, the training periods should be to distributed to be completed in a year for enabling the student teacher to follow all the activities during a full year and building friendly relationships among student teachers, teachers and those participating in the evaluation process.

\section{Smith's Study (2000)}

The study aimed at identifying the general problems faced by the student teachers who completed the practicum program through analyzing the previous related literature and categorizing data according to Foler model (1969) to improve the teacher's interests in relation to three areas of interest: self-concern, duty and students impressing. The results of the study showed five main ideas representing self-concern sides: classroom discipline, personal and scholastic adaptation, features and personal traits and two main ideas representing interesting in the instructional 
tasks management which were: methods, strategies and working with the special needs students.

Student teachers' preparation programs were asserted by a considerable amount of research. Furthermore, attention to the student teachers' preparation and solving their problems in order to achieve better future is of crucial importance. Furthermore, those problems were indicators of sophisticated difficulties in the future; Consequently, the study analyzed and categorized the studies in a model assisting in improving the student teacher's performance (Loock, 1977; Ransom, Weisenbach, and Zetzl,1987).

16. Julian's Study (1998)

The study aimed at delineating the problems faced by those taking part in the practicum program, namely, the school mangers (males or females), student teachers, academic supervisors in the primary and the secondary schools of New Zealand. Personal interviews, as an instrument for collecting data, was adopted. The results of the study showed that there were severe shortage in the materials and the financial facilities and insufficiency of the financial assistance required for administration.

\section{Critical analysis of the previous studies:}

- The previous studies portrayed the importance of the practicum program in the teacher preparation as it is linked to preparing the future teacher, and the importance of treating the points of weakness if appeared in relation to all those involved in the practicum program, namely, the academic supervisors, student teachers (males or females), the cooperating teacher or the cooperating school.

- The participants of the previous studies were different individuals who had direct relationship with the practicum program like the student teachers, the academic supervisors, the cooperating teacher and the cooperating school. On the other hand, the current study treated the problems, related to the previous categories, encountered 
مجلة كلية التربية، جامعة الأزهر ، العدد: ( • V الجزء الثاني) أكتوبر لسنة 17 • بام

by the student teachers, as viewed by the student teachers themselves.

- The previous studies assisted in formulating the current study problem, designing and forming the study instrument (the questionnaire).

- The current study is considered a unique one as it investigated the specialization variable (English student teachers) and delineated the most prevalent reasons caused the study problem.

- The current study focused on the practicum problems encountered by the student teachers as viewed by the student teachers themselves. Furthermore the current study did not investigate the practicum program or those participating in the program, but the study focused on the student teachers.

- The current study is considered a complement to the previous studies investigating this significant issue. Moreover, the current study is unique in studying the practicum program problems as viewed by the English Branch student teachers which may contribute in portraying the factors causing the practicum program problems and difficulties in an objective way and providing the suitable solutions.

- The current study conducted a pilot study for asking the students who completed their practicum programs in the semester preceded the semester in which the study was conducted for identifying the points of views of the participants of the program concerning their the encountered problems. 


\section{Results of the study:}

\section{Question One:}

- What are the problems, encountered by the student teachers during the practicum period, related to the academic supervisor?

For answering the previous question, the researcher calculated the arithmetic means, standard deviations and the percentages of the item in the questionnaire related to the academic supervisor. The following table (1) delineated the problems encountered by the student teachers in relation to the academic supervisor and the arithmetic means, standard deviations and the percentages of every item.

Table (1): The problems related to the academic supervisors

\begin{tabular}{|c|c|c|c|c|}
\hline No & The First Dimension & $\begin{array}{l}\text { Arithme } \\
\text { tic Mean }\end{array}$ & \begin{tabular}{|l|} 
Standard \\
Deviation
\end{tabular} & $\begin{array}{l}\text { Perce } \\
\text { ntage }\end{array}$ \\
\hline$\varepsilon$ & $\begin{array}{l}\text { The academic supervisor rarely hold } \\
\text { collective discussion with the student } \\
\text { teachers. }\end{array}$ & $r, Y \diamond \wedge$ & $1, \varepsilon \cdot 1 \wedge r$ & $\%$ Y , \\
\hline r & $\begin{array}{l}\text { The academic supervisor work is } \\
\text { delimited to evaluating the student } \\
\text { teachers not guiding them to sharpen } \\
\text { their teaching skills. }\end{array}$ & $r, 11 r q$ & $1,7 Y \cdot 71$ & $\% 19, \varepsilon$ \\
\hline 1 & $\begin{array}{l}\text { The academic supervisor does not visit } \\
\text { the student teachers during the } \\
\text { practicum period. }\end{array}$ & $r, q \wedge r q$ & 1,OVMYY & $\%$ \% , \\
\hline 0 & $\begin{array}{l}\text { The academic supervisor does not } \\
\text { inform the student teachers about the } \\
\text { supervising visit time. }\end{array}$ & $p, q \wedge r q$ & 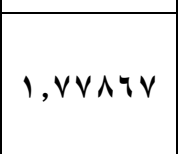 & $\% 11, r$ \\
\hline$v$ & $\begin{array}{l}\text { The academic supervisor asks the } \\
\text { student teachers to do extra work that is } \\
\text { not related to the practicum program. }\end{array}$ & $r, q \wedge r q$ & $1, \vee 0.1$ & \% \\
\hline$\Lambda$ & $\begin{array}{l}\text { The academic supervisor does not } \\
\text { accept the student teachers points of } \\
\text { views. }\end{array}$ & $r, q \cdot r r$ & $1,7 \wedge 71$ & $\% 1 r, 9$ \\
\hline
\end{tabular}


مجلة كلية التربية، جامعة الأزهر، العدد: ( • V الجزء الثاني) أكتوبر لسنة ج 1 • rم

\begin{tabular}{|c|c|c|c|c|}
\hline No & The First Dimension & $\begin{array}{l}\text { Arithme } \\
\text { tic Mean }\end{array}$ & $\begin{array}{l}\text { Standard } \\
\text { Deviation }\end{array}$ & $\begin{array}{l}\text { Perce } \\
\text { ntage }\end{array}$ \\
\hline$r$ & $\begin{array}{l}\text { The academic supervisor does not } \\
\text { present sufficient improving feedback } \\
\text { during the supervision visit. }\end{array}$ & $r, V \vee \leq r$ & $1, \leqslant 9 \vee \vee 0$ & $\% 19, \varepsilon$ \\
\hline 7 & $\begin{array}{l}\text { The academic supervisor does not revise } \\
\text { the lesson plan for providing } \\
\text { appropriate feedback. }\end{array}$ & $r, V \bullet \wedge I$ & $1, \leqslant \wedge 9 \vee$ & \% Y , \\
\hline
\end{tabular}

Table (1) showed that the problems encountered by the student teachers in relation to the academic supervisor were the items $(2,4,1,7,6,8,3,6)$. The arithmetic mean of the items representing the problems were ranged between $(2.75-3.25)$, and the percentages were ranged between $(11.3 \%$ - $21.0 \%)$; consequently, the problems were considered as moderately severe ones.

Question Two:

- What are the problems, encountered by the student teachers during the practicum period, related to the cooperating teacher?

For answering the previous question, the researcher calculated the arithmetic means, standard deviations and the percentages of the item in the questionnaire related to the cooperating teacher. The following table (2) delineated the problems encountered by the student teachers in relation to the cooperating teacher and the arithmetic means, standard deviations and the percentages of every item. 
مجلة كلية التربية، جامعة الأزهر، العدد: ( • V الجزء الثاني) أكتوبر لسنة ج 1 • rم

Table (2): The problems related to the cooperating teacher

\begin{tabular}{|c|c|c|c|c|}
\hline No & The Second Dimension & $\begin{array}{l}\text { Arithme } \\
\text { tic Mean }\end{array}$ & $\begin{array}{l}\text { Standard } \\
\text { Deviation }\end{array}$ & $\begin{array}{l}\text { Perce } \\
\text { ntage }\end{array}$ \\
\hline 11 & $\begin{array}{l}\text { The cooperating teacher } \\
\text { misunderstands her specific roles. }\end{array}$ & $r, \cdot \Lambda \cdot \tau$ & $1,7 \leqslant Y \neg 0$ & $\% \wedge, 1$ \\
\hline Ir & $\begin{array}{l}\text { The cooperating teacher does not } \\
\text { enhance the student teachers' points of } \\
\text { strength. }\end{array}$ & $r$ & $1,0 \wedge \wedge 9$ & $\% 17,1$ \\
\hline$v$ & $\begin{array}{l}\text { The cooperating teacher does not } \\
\text { provide suitable feedback after lesson } \\
\text { teaching by the student teacher. }\end{array}$ & $r, q \wedge r q$ & $1,7 \leqslant \leqslant 0 \wedge$ & $\% 1 r, q$ \\
\hline 1 & $\begin{array}{l}\text { The cooperating teacher is not } \\
\text { interested in supervising the student } \\
\text { teachers. }\end{array}$ & r,AVI & $1,0 \leqslant 17$ & $\% 19, \varepsilon$ \\
\hline ○ & $\begin{array}{l}\text { The student teachers face difficulty in } \\
\text { interaction with the cooperating } \\
\text { teacher. }\end{array}$ & $r, \Lambda \cdot 70$ & $1, \vee Y \odot V \wedge$ & $\% 7,0$ \\
\hline$\Lambda$ & $\begin{array}{l}\text { Lesson planning method is not paid the } \\
\text { due attention. }\end{array}$ & $r, V V \leq r$ & 1,00101 & $\%$ IV, V \\
\hline$r$ & $\begin{array}{l}\text { The cooperating teacher cannot use the } \\
\text { new technologies in explaining the } \\
\text { lessons. }\end{array}$ & $r, V \cdot q V$ & $1, \leqslant 7 \leqslant 19$ & $\% 17,1$ \\
\hline 1. & $\begin{array}{l}\text { The cooperating teacher brusquely } \\
\text { treats the student teachers. }\end{array}$ & $r, Y \leqslant \Delta r$ & $1,7 \wedge \cdot 1 \%$ & $\% 1 r, q$ \\
\hline r & $\begin{array}{l}\text { The cooperating teacher focuses on } \\
\text { some specific issues and neglects the } \\
\text { others. }\end{array}$ & r, ד rq & & $\% \mu, \theta$ \\
\hline$\varepsilon$ & $\begin{array}{l}\text { Some cooperating teachers delegate the } \\
\text { student teachers to explain the lessons } \\
\text { instead of them without supervision. }\end{array}$ & $Y, \diamond \wedge \cdot \neg$ & $1,0 \leqslant r Y \wedge$ & $\%$ IV, \\
\hline 9 & $\begin{array}{l}\text { The cooperating teacher does not allow } \\
\text { the student teachers to explain more } \\
\text { than one complete session. }\end{array}$ & $Y,\{017$ & $1,0 \ldots 0 v$ & $\% \wedge, 1$ \\
\hline 7 & $\begin{array}{l}\text { The cooperating teachers do not pay } \\
\text { attention to the activities related to } \\
\text { curriculum informally. }\end{array}$ & $r, r \circ \leq \Lambda$ & q & $\% 1 r, q$ \\
\hline
\end{tabular}

It is clear from the above table (1) that the most prevalent problems in relation to the "cooperating teacher" were the problems $(11,12,7,3,8,5,1,10,2,4)$. The arithmetic means of the items delineating the problems were ranged between $(2.85-$ 
3.0). The percentage of the items representing the problems were ranged between $(17.7 \%-8.1 \%)$; consequently, the problems were considered as moderately severe ones.

The arithmetic means of the problems $(6,9)$ were ranged between $(2.45-2.35)$ and their percentages were ranged between $(2.53 \%-6.51 \%)$; consequently, the problems were considered as relatively severe ones.

Question three:

- What are the problems, encountered by the student teachers during the practicum period, related to the cooperating school?

For answering the previous question, the researcher calculated the arithmetic means, standard deviations and the percentages of the item in the questionnaire related to the cooperating school. The following table (3) delineated the problems encountered by the student teachers in relation to the cooperating school and the arithmetic means, standard deviations and the percentages of every item. 


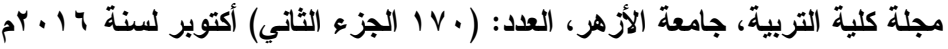

Table (3): The problems related to the cooperating school

\begin{tabular}{|c|c|c|c|c|}
\hline No & The Third Dimension & $\begin{array}{l}\text { Arithme } \\
\text { tic Mean }\end{array}$ & $\begin{array}{l}\text { Standard } \\
\text { Deviation }\end{array}$ & $\begin{array}{l}\text { Perce } \\
\text { ntage }\end{array}$ \\
\hline 4 & $\begin{array}{l}\text { The cooperating school engages some } \\
\text { student teachers with tasks other than } \\
\text { teaching like attending the spare } \\
\text { sessions. }\end{array}$ & $r, v \cdot q v$ & $1, r q \circ r q$ & $\% 17,1$ \\
\hline 2 & $\begin{array}{l}\text { The cooperating school administration } \\
\text { has low confidence in the student } \\
\text { teachers. }\end{array}$ & r, r & $1,0 \wedge .00$ & $\% 17,1$ \\
\hline 3 & $\begin{array}{l}\text { The cooperating school provides limited } \\
\text { support for the student teachers. }\end{array}$ & $r, 11 r q$ & $1, \varepsilon 71 \cdot r$ & $\% 17, \varepsilon$ \\
\hline 7 & $\begin{array}{l}\text { The cooperating school does not } \\
\text { friendly welcome the student teachers. }\end{array}$ & $r, .171$ & 1, & $\% 11, r$ \\
\hline 5 & $\begin{array}{l}\text { The cooperating school imposes strict } \\
\text { directions in relation to the student } \\
\text { teachers. }\end{array}$ & ५, q ४VV & $1,01 \leq 7$ & $\%$ \% \\
\hline 1 & $\begin{array}{l}\text { The cooperating school does not treat } \\
\text { the problems encountered by the } \\
\text { student teachers. }\end{array}$ & $r, \wedge \wedge \vee 1$ & $1,0 \leqslant \wedge 19$ & $\%$ I,$v$ \\
\hline 6 & $\begin{array}{l}\text { The cooperating school administration } \\
\text { does not supervise the punctuality of } \\
\text { the student teachers during the } \\
\text { practicum period. }\end{array}$ & $r, \varepsilon 19 \leqslant$ & $1, \varepsilon \leqslant r \leqslant 0$ & $\% q, v$ \\
\hline
\end{tabular}

Table (4) revealed that the main problem related to the cooperating school was the problem (4) as the arithmetic mean was (3.70) and the percentage was $(16.1 \%)$; consequently, the problem was considered as a severe one. The arithmetic means of the problems $(2,3,7,5,1)$ were ranged between $(3.16-2.88)$ and the percentages were ranged between $(17.7 \%-16.1 \%)$; consequently, the problems were considered as moderately severe ones. In relation to the problem (6), the arithmetic mean was (2.41) and the percentage was $(9.7 \%)$; consequently, the problem was considered as a relatively severe one. 
Question Four:

- What are the problems, encountered by the student teachers during the practicum period, related to the student teacher?

For answering the previous question, the researcher calculated the arithmetic means, standard deviations and the percentages of the item in the questionnaire related to the student teachers. The following table (2) delineated the problems encountered by the student teachers and the arithmetic means, standard deviations and the percentages of every item.

Table (4): The problems related to the student teachers

\begin{tabular}{|c|c|c|c|c|}
\hline No & The Fourth Dimension & $\begin{array}{l}\text { Arithmeti } \\
\text { c Mean }\end{array}$ & $\begin{array}{l}\text { Standard } \\
\text { Deviation }\end{array}$ & $\begin{array}{l}\text { Percen } \\
\text { tage }\end{array}$ \\
\hline r & $\begin{array}{l}\text { The student books and the teachers' } \\
\text { guide books are not available during the } \\
\text { practicum period. }\end{array}$ & r, TVV & $1,01 Y 01$ & $\% 1 r, 1$ \\
\hline 17 & $\begin{array}{l}\text { The student teachers are engaged in } \\
\text { studying the college subjects during the } \\
\text { practicum period. }\end{array}$ & צr, & 1,0.17 & $\% 1 \mathrm{v}, \mathrm{V}$ \\
\hline $1 \varepsilon$ & $\begin{array}{l}\text { The student teachers are afraid of the } \\
\text { academic supervisor's evaluation. }\end{array}$ & $r, r Y \diamond \wedge$ & $1,0 \leq .91$ & $\% 17,1$ \\
\hline$\varepsilon$ & $\begin{array}{l}\text { The student teachers suffer from } \\
\text { confusion when the academic supervisor } \\
\text { attends the session. }\end{array}$ & r,1 & $1, \leq 17 \leq 7$ & $\%$ \% , \\
\hline v & $\begin{array}{l}\text { The student teachers face difficulty in } \\
\text { dealing with the slow learners. }\end{array}$ & $r, \wedge \cdot q$ & $1,01 \wedge 1 \wedge$ & $\%$ IV, $\vee$ \\
\hline 1 & $\begin{array}{l}\text { The student teachers have not solid } \\
\text { background in the target subject. }\end{array}$ & $r$ & 1,0 & $\% 1 r, q$ \\
\hline Ir & $\begin{array}{l}\text { The student teachers face difficulties in } \\
\text { preparing the instructional media } \\
\text { during the practicum period because of } \\
\text { the time insufficiency. }\end{array}$ & $r$ & $1, \leqslant q 410$ & $\% 17,1$ \\
\hline
\end{tabular}




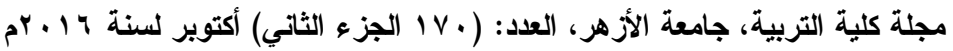

\begin{tabular}{|c|c|c|c|c|}
\hline No & The Fourth Dimension & $\begin{array}{l}\text { Arithmeti } \\
\text { c Mean }\end{array}$ & $\begin{array}{l}\text { Standard } \\
\text { Deviation }\end{array}$ & $\begin{array}{l}\text { Percen } \\
\text { tage }\end{array}$ \\
\hline 11 & $\begin{array}{l}\text { There is a contradiction between the } \\
\text { feedback provided by the academic } \\
\text { supervisor and that of the cooperating } \\
\text { teacher. }\end{array}$ & $r, V \vee \leq r$ & 1,71\%4 & $\% 1 r, q$ \\
\hline 10 & $\begin{array}{l}\text { The student teachers do not know their } \\
\text { required roles. }\end{array}$ & $Y, \vee \bullet \wedge I$ & 1,09090 & $\% \wedge, 1$ \\
\hline 7 & $\begin{array}{l}\text { The student teachers are unable to } \\
\text { manage and control the classroom. }\end{array}$ & $Y, V \leq 19$ & $1,07 \vee \leq 0$ & $\% 17,1$ \\
\hline$\Lambda$ & $\begin{array}{l}\text { The student teachers are unable to meet } \\
\text { the individual differences. }\end{array}$ & $r, V \cdot q V$ & $1,0191 \leq$ & $\% 1 \leq, 0$ \\
\hline ir & $\begin{array}{l}\text { The student teachers are unable to use } \\
\text { suitable language for the students' age. }\end{array}$ & Y, TVV & 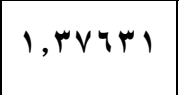 & $\% Y \leq, r$ \\
\hline iv & $\begin{array}{l}\text { The student teachers feel embarrassed } \\
\text { when committing error in front of the } \\
\text { students. }\end{array}$ & $Y, Y \leqslant 0 Y$ & $1,0791 \leq$ & $\% 1 \leq, 0$ \\
\hline$\bullet$ & $\begin{array}{l}\text { The student teachers feel confused when } \\
\text { the cooperating teacher enters the class } \\
\text { for evaluation. }\end{array}$ & r, Trq & $1, \varepsilon .0 r$ & $\% r r, r$ \\
\hline 1 . & $\begin{array}{l}\text { The student teachers are unable to } \\
\text { deliver the information to the students. }\end{array}$ & $\uparrow, \diamond \wedge \cdot \uparrow$ & $1,7 r 010$ & $\% 1 r, q$ \\
\hline 19 & $\begin{array}{l}\text { The student teacher are not motivated } \\
\text { to teach. }\end{array}$ & $Y, \diamond \wedge \cdot \uparrow$ & $1,77 \leqslant 97$ & $\% 1 r, q$ \\
\hline 11 & $\begin{array}{l}\text { The student teachers are not competent } \\
\text { in teaching the intended curriculum. }\end{array}$ & Y,,$~ \curlyvee \leqslant 0$ & $1,7 \vee 0 \leqslant \Lambda$ & $\% 1 r, q$ \\
\hline 9 & $\begin{array}{l}\text { The student teachers are unable to } \\
\text { reinforce the student teachers' } \\
\text { performance in the exact time. }\end{array}$ & $r,\{r \diamond 0$ & $1,0 \wedge \leq 9 \wedge$ & $\% 1 \leq, 0$ \\
\hline$r$ & $\begin{array}{l}\text { The practicum period is just only one } \\
\text { semester. }\end{array}$ & $r, r, q V$ & $1, r \wedge \cdot 7 r$ & $\% 11, r$ \\
\hline
\end{tabular}

Table (4) showed that the main problem in relation to the student teachers was the problem (2) as the arithmetic mean was (3.67) and the percentage was (13.1) which indicated that the problem was severe. On the hand, in relation to the problems (16, 


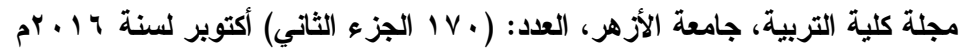

$14,4,7,1,12,11,15,6,8,13,17,5,10,19,18)$, the arithmetic means were ranged between $(2.56-3.67)$ and the percentages were ranged between $(12.9 \%-17.7-\%)$; consequently, the problems were considered as moderately severe ones.

The arithmetic mean of the problems (3-9) were ranged between $(3.43-2.20)$ and the percentages were ranged between $(11.3 \%$ - 14.5\%); consequently, the problems were considered as relatively severe ones.

\section{Results discussion and interpretation:}

\section{Discussion of the First Question:}

- What are the problems, encountered by the student teachers during the practicum period, related to the academic supervisor?

The results of the research showed, according to table (1), that the problems related to the academic supervisor came third in relation to the problem severity. It was also detected that the most critical problems in this dimension were that (the academic supervisor rarely holds collective discussion with the student teachers; the academic supervisor work is limited to evaluating the student teachers not guiding them to sharpen their teaching skills; the academic supervisor does not visit the student teachers during the practicum period; the academic supervisor does not inform the student teachers about the supervising visit time; the academic supervisor asks the student teachers to do extra work that is not related to the practicum program; the academic supervisor does not present sufficient improving feedback during the supervision visit; and the academic supervisor does not revise the lesson plan for providing appropriate feedback. All these problems were severe ones and affect the student teachers' performance in the practicum program. The results attained in this dimension agreed with that of Al-Khwalda and Ahmida's study (2010), Abo Shendy, et.al. Study (2009), and Shaheen's study (2010). The results attained indicated that the academic supervisors do not do their roles effectively. In addition, they do not provide the suitable improving feedback during their periodic meetings and guide the student teachers to achieve effective

$$
-V \mu V-
$$


teaching practices. Moreover, many academic supervisors participating in the practicum program do not know their roles precisely which lead to confusion and misunderstanding of the tasks, so many researchers realized that the effectiveness of the academic supervisors contributes greatly in the practicum program success (Allen, Ambrosetti, and Turner, 2013, and Sokal \& Woloshyn, 2013).

\section{Discussion of the Second Question:}

- What are the problems, encountered by the student teachers during the practicum period, related to the cooperating teacher?

The research results in relation to the student teachers, according to table (2), showed that the moderately severe problems encountered by the student teachers were that the (the cooperating teacher misunderstands her specific roles; the cooperating teacher does not enhance the student teachers' points of strength; the cooperating teacher does not provide suitable feedback after lesson teaching by the student teachers; the cooperating teacher is not interested in supervising the student teachers; the student teachers face difficulty in interaction with the cooperating teacher; the lesson planning method is unimportant; and the cooperating teacher brusquely treat the student teachers.

It is clear from the above mentioned results that the cooperating teacher do not cooperate with the student teachers; consequently, the Practicum Program Unit (at the faculty) should do their best to select the most effective teachers. Furthermore, the academic supervisors should do their best to encourage cooperation and love among the cooperating teachers and the student teachers. Consequently, the cooperation among the student teachers and the cooperating teacher may contribute in helping the cooperating teacher do her roles effectively. The results attained are consistent with the studies of (Al-Sayda \& Mahasna, 2015; Al-Aagez \& Hels, 2011; Al-Khwalda \& Ahmida, 2010, As-salmy). 


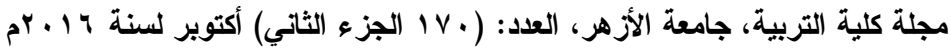

The problems $(4,9,6)$ were relatively severe problems as their arithmetic means were ranged between $(2.35,2.580)$ and came last in relation to the order of their effect. These attained results may be attributed to the lack of confidence between the cooperating teacher and the student teachers, as the cooperating teacher believes that the student teacher is unable to hold the responsibility of teaching more than two sessions. The abandoning of the activities related informally to the curriculum may be attributed to the cooperating teacher's consideration of the activities related informally to the curriculum as they extra parts of the curriculum; Consequently, all these factors may cause frustration for the student teachers (Kiggundu, 2007, and AlSayda \& Mahasna, 2015).

\section{Discussion of the Third Question:}

- What are the problems, encountered by the student teachers during the practicum period, related to the cooperating school?

The results of the study in this dimension showed that engaging the student teachers with tasks other than teaching like attending the spare sessions came first. The arithmetic mean of that problem was (3.70) which indicated that the problem was severe. That result may be attributed to driving benefits from the student teachers when the teachers are absent.

On the other hand, the rest of the items in this dimensions which their arithmetic means were ranged between $(3.16-2.88)$ were moderately severe problems. These problems were that the (the cooperating school administration has low confidence in the student teachers; the cooperating school provides limited support for the student teachers; the cooperating school does not friendly welcome the student teachers; the cooperating school imposes strict directions in relation to the student teachers; and the cooperating school does not treat the problems encountered by the student teachers.

The above mentioned problems showed clearly that there were no positive social atmosphere that may urge the student teachers to form negative attitudes towards the teaching 
profession as was asserted by many studies (Al-Sayda \& Mahasna, 2015; Kiggundu, 2007; and Allen \& Ambroserri 2013; Shaheen, 2010).

The sixth problem indicating that the cooperating school administration does not supervise the punctuality of the student teachers during the practicum period got $(2.41)$ arithmetic mean, which indicated that the problem was a relatively severe one. The result attained may be attributed to the school principal that the student teachers are in a training and their absence would not make change in the cooperating school.

\section{Discussion of the Fourth Question:}

- What are the problems, encountered by the student teachers during the practicum period, related to the student teacher?

The results of the study related to the student teachers showed that the student teachers' problem was that the second problem is among the four main dimensions that cause the problems for the student teachers during the period of the practicum. The most widespread problem was that the student books and the teachers' guide books are not available during the practicum program period as the arithmetic mean of that problem was (3.67) indicating that the problem is severe in relation to the student teachers and the problem negatively affects their performance during the lesson planning stage. The current problem may be attributed to the fact that the cooperating teacher does not provide the student teachers with the materials and the student could not get them to be utilized in preparing the lessons (Kiggundu, 2007).

The problems $(16,14,4,7,1,12,11,15,6,8,13,17,5)$ were moderately severe as the highest arithmetic mean was (3.32) and the smallest one was (2.62). Consequently, the results can be interpreted as follows:-

- Engaging the student teachers in studying the faculty subjects during the practicum period is considered a moderately severe problem, as the student teachers are not free to focus on the practicum program. With this in mind, the extra work may cause contradiction 
between the faculty schedule and the practicum period which may cause stress and anxiety for the student teachers during the practicum period. Consequently, these problems may negatively affect the student teachers' performance as they just learn their future professional career. The results attained are agreed with that of (Al-Khwalda \& Ahmida, 2010; Shaheen, 2010, and As-salmy).

- The results attained in relation to the items $(14,4,6$, 11), which include the following problems (the student teachers are afraid of the academic supervisor's evaluation, the student teachers suffer from confusion when the academic supervisor attends the session, and the contradiction between the academic supervisor feedback and that of the cooperating teacher), may be attributed to the student teachers worrying about the cumulative degree because of the low degrees of evaluation provided by the academic supervisor as the credit hours of the practicum program are only (8) hours. The practicum program needs exerting condensed efforts by the student teachers in relation to the planning and the implementation of the lessons, preparing the instructional media and the activities and the other components related to the teaching profession. Furthermore, the disagreement between the academic supervisor and the cooperating teacher instructions in relation to the feedback provided make the student teachers worried and, in turn, their performance is negatively affected. The previously mentioned results are consistent with that of (Abo Shendy, et.al., 2009 \& Sokal and woloshyn, 2013)

- The problems $(15,6,8,13,17,10,19,18)$ were considered as moderately severe ones in relation to the student teachers as they may be psychologically and educationally unprepared for the practicum program. The problem of the student teachers' insufficient preparation in relation to the practicum program is agreed with that of (Nonis \& Tan, 2014; Sokal and

$$
-V \leqslant 1-
$$




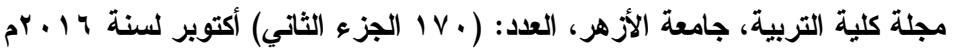

woloshyn, 2013, Kiggundu,2007; Smith, 2000 \& AlAstal, 2004).

- The rest of the problems (3-9) were relatively severe ones, which indicate that the problems do not affect the student teachers' performance greatly and directly.

\section{Recommendations:}

In the light of the results attained, the following recommendations seem pertinent:

1) A complete semester should be allocated for the practicum program to enable the student teachers acquire and practice the target experiences planned for the student teachers.

2) Carefully assigning the cooperating schools to be suitable for practicing teaching in relation to the cooperating teachers and the availability of the physical and the human resources.

3) Training contractions should be employed between the cooperating schools and the university in order to achieve successful and effective training.

4) Scheduling regular meetings between the educational supervision administration and the university.

5) Setting up training workshops for the student teachers to thoroughly understand the practicum program and understand their duties and their rights.

6) Regular meetings should be held among the academic supervisor, the cooperating teacher and the student teachers in order to discuss the points of weakness and strength of the practicum program.

7) The student teachers should be mentally prepared, which may increase the level of proficiency and achievement. 
References:

Abo Shendy, Yosef, A., Abo Shaira, Khalid, M. et. al. (2009). Evaluation of the practicum program at Zarqa Private University and suggestions for evaluation. Zarqa Journal for Humanities. 9 (3).pp.37-66.

Al-Aagez, F. A., \& Hels, D. D. (2011). The status quo of the practicum programs at the Islamic University of Gaza, Faculty of Education. The Islamic University Journal (The Humanities Series), $1{ }^{q}\left({ }^{r}\right)$.pp.1-46.

Al-Astal, I. H. (2004). Studying the most important problems encountered by the student teachers during the practicum period at the College of Education and the Basic Sciences, Ajman University of Science and Technology. Educational Science Journal, (6), Journal of Educational Science ,University of Qatar, 6 edition, pp.143-181.

Al-Khwalda, M. F., Ahmida, F. M. et.al. (2010). The problems encountered by the student teachers at Queen Rania Faculty for Childhood, Hashemite University. Damascus University Journal, r ז(r). Pp737-781.

Allen, J. M., Ambrosetti, A., \& Turner, D. (2013). How school and university supervising staff perceive the pre-service teacher education practicum: A comparative study. Australian Journal of Teacher Education, 38(4), 108-128.

Al-Masry, W. S. (2010). Obstacles of the practicum program among the Branch of Physics students, Faculty of Education, Al-Aqsa University - Gaza as a sample for evaluation, Al-Azhar University Journal in Gaza (The Humanities Series), 12(2).pp 509-536.

Almotlk, F. S. (2010). The status quo of the practicum program of the student teachers at the Faculty of Education, Damascus University and the methods of development (field study for the fourth year student teachers), Damascus University Journal. ${ }^{\top}{ }^{\top}(r-1)$.pp 61-96. 


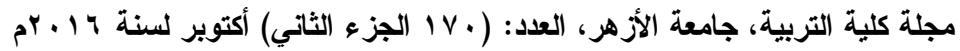

Al-Sayda, M. A., \& Mahasna, O.M. (2015). The problems encountered by the professional education students at AlBalqa' Applied University during the practicum program. Studies in Educational Science. $\leq$ Y ( 1).pp 13-29.

Edwards, M. (1993). What is wrong with practicum?: some reflections. The South Pacific Journal of Teacher Education, 21(1), 33-43.

Julian, R. (1998). Provider proliferation: Progress or problems for the practicum. A study of teaching practice in times of expansion. Wellington, New Zealand: New Zealand Council for Educational Research.

Khasawna, Kh. A. S. (2014). The Efficiency of the practicum program at Hael University as viewed by the student teachers, University of Hail.

Khazer, \& Mohand. (2007). The Practicum program problems at Mooata University as viewed by the cooperating school administration. Studies in Educational Science. 2(34). pp 244-258.

Kiggundu, E. (2011). Teaching practice in the Greater Vaal Triangle Area: The student teachers experience. Journal of College Teaching \& Learning (TLC), 4(6).

Lock, C.R. (1977). Problems of secondary school student teachers. The Teacher Educators, 13(1), 30-40.

Nonis, K. P., \& Tan, J. S. Y. (2011). Beginner pre-service special education teachers' learning experience during practicum.

Ransom, P.E., L. Weisenbach, \& M.Zetzl (1992). Perceptions of the Reading Process and reading instruction by pre-service teacher. Paper presented at the meeting of the American Reading Forum, Sanibel Island, USA.

Shaheen, M. A. (2010). The practicum program problems of the practicum curriculum at Al-Quds Open University as viewed by the student teachers. Al-Quds Open University. Palestine. 


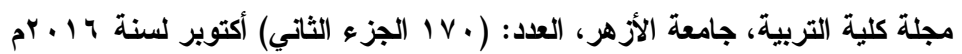

Smith, B. P. (2000). Emerging themes in problems experienced by student teachers: A framework for analysis. College Student Journal, 34(4), 633-633.

Sokal, L., Woloshyn, D., \& Funk-Unrau, S. (2014). How important is practicum to pre-service teacher development for inclusive teaching? Effects on efficacy in classroom management. Alberta Journal of Educational Research, 59(2), 285-298. 